\title{
The East Variscan Shear Zone: a structural and geochronological review for improving paleogeographic reconstruction of the southern Variscides
}

\author{
Matteo Simonetti (1)
}

\author{
(1) Dipartimento per il Servizio Geologico d'Italia, ISPRA, 00144 Roma, Italy \\ Corresponding author e-mail: matteo.simonetti@isprambiente.it \\ Document type: Article. \\ Manuscript received 23 March 2021; accepted 05 November 2021; editorial responsibility and handling by F. Cifelli.
}

\section{ABSTRACT}

The Alpine orogenesis partially overprinted the Southern European Variscan Belt complicating paleogeographic reconstructions. A main debate concerns the extension and the tectonic significance of the regional-scale East Variscan Shear Zone (EVSZ). This work reviews the data obtained thanks to a systematic and multidisciplinary study of the Ferriere-Mollières shear zone in the Argentera Massif, the Emosson-Bèrard shear zone in the Aiguilles Rouge Massif and the Cavalaire Fault in the Maures Massif. A pure shear-dominated transpression with a a variable component of simple shear is recognized in the studied shear zones. Syn-kinematic paragenesis, microstructures and quartz c-axis fabrics revealed synshear decreasing temperature starting from amphibolite-facies. Petrochronology constrained the timing of deformation. Ages range between $\sim 340-330 \mathrm{Ma}$ and $\sim 320 \mathrm{Ma}$. Older ages are interpreted as the beginning of the activity of the EVSZ along its older branches (Ferriere-Mollières shear zone) while ages of $\sim 320 \mathrm{Ma}$, obtained in all the shear zones, demonstrate that they were active at the same time. The data revealed a similar tectono-metamorphic evolution of the shear zones and highlights that transpressional deformation affected the European Variscan Belt after the metamorphic peak linked to the initial collisional stage. The review constrains the extension, the kinematics and the timing the EVSZ.

KEY WORDS: East Variscan Shear Zone, Argentera Massif, Aiguilles Rouge Massif, Maures Massif, Structural Analysis.

\section{INTRODUCTION}

The Variscan Belt in Europe results from a DevonianCarboniferous continent-continent collision between Laurentia-Baltica and Gondwana (Arthaud \& Matte, 1977; Burg \& Matte, 1978; Tollmann, 1982; Matte, 1986, 2001). It is characterized by a composite orocline showing two large scale arcs (Matte, 1986, 2001): a western branch, the IberoArmorican arc (Arthaud \& Matte, 1977; Dias \& Ribeiro, 1995; Matte, 2001; Dias et al., 2016; Fernández-Lozano et al., 2016), and a smaller eastern branch (Matte, 2001; Bellot, 2005; Ballèvre et al., 2018). Some authors proposed that this arc is delimited by a regional-scale dextral transpressive shear zone known as the East Variscan Shear Zone (EVSZ; Corsini \& Rolland, 2009; Carosi et al., 2012; Padovano et al., 2012, 2014; Simonetti et al., 2018, 2020a). This led some authors (Matte, 2001; Kroner \& Romer, 2013; Dias et al., 2016; Simonetti et al., 2018) to hypothesize that the Variscan Belt in Europe developed and evolved in a manner analogous to the indentation model proposed by Tapponnier \& Molnar (1977) and Tapponnier et al. (1982).

The EVSZ is actually not completely understood, in particular in those sectors of the Variscan Belt that are now part of the Alps, and its role during the Variscan and post-Variscan time is still debated. According to some authors, shear deformation along the EVSZ in the Variscan basement of the Western Alps is related to the possible transition between Pangea B to Pangea A that started during the Permian (Muttoni et al., 2003, 2009).

However, it is not clear which structures would have allowed the movement of Gondwana, and if their remnants are still recognizable. Some authors proposed as evidence in support of this model the extensive presence of preAlpine dextral shear in the fragments of the Variscan Belt in the Mediterranean area coupled with the formation of Early Permian basins (Muttoni et al., 2003; Muttoni \& Kent, 2019).

In contrast with this hypotesis, geochronological data from pre-Alpine shear zones in the Western Alps point out to an older deformation still related to the Variscan orogeny (Pohl et al., 2018; Simonetti et al., 2018; Simonetti et al., 2020a, 2021c) suggesting that the activity on the EVSZ is not related to the post-Variscan events. A detailed structural and geochronological analysis of the shear zones in the Variscan basement of the Western Alps is therefore necessary to address this problem.

Another unclear point concerns the lateral relationships between the Corsica-Sardinia block, the Maures-Tanneron Massif and the Variscan basement of the Western Alps (External Crystalline Massifs). The correlation between those sectors is still debated and is mostly based on lithological and stratigraphic affinities and paleomagnetic data. In particular, it is not clear if the Corsica-Sardinia Block was connected to Iberia (Stampfli et al., 2002; Turco et al., 2012) or to southern France (Rosenbaum et al., 2002; Advokaat et al., 2014) during the Late Carboniferous times.

The focus of this review are three fragments of the Variscan Belt: the Argentera Massif and the Aiguilles Rouges Massif, that belong to the Alpine External Crystalline Massifs, and the Maures Massif in southern France. 
The major ductile shear zones in those sectors were recently studied following a systematic multidisciplinary approach that combines field work, structural and microstructural analysis, kinematic vorticity analysis, quartz microstructure and fabric analysis and U-Th- $\mathrm{Pb}$ monazite petrochronology. The new results are compared with the data from the Posa-Asinara shear zone in order to better constrain the extension and the complex evolution of the EVSZ as well as to improve the for paleogeographic reconstruction of the southern Variscides.

\section{GEOLOGICAL SETTING OF THE VARISCAN BELT}

The Variscan Belt is the result of a continent-continent collision between Laurentia-Baltica and Gondwana that occurred between $380 \mathrm{Ma}$ and $280 \mathrm{Ma}$ (Arthaud \& Matte, 1977; Burg \& Matte, 1978; Tollmann, 1982; Matte, 2001; Di Vincenzo et al., 2004). This collision led to the final assemblage of Pangea and to the formation of a 1000 $\mathrm{km}$ wide and $8000 \mathrm{~km}$ long mountain system, which extended from the Caucasus to the Appalachian and Ouachita mountains of northern America at the end of the Carboniferous (Matte, 2001).

The main debate concerning the Variscan collision in Europe is about the presence or absence of microplates between Laurentia-Baltica and Gondwana. Some authors identified these small microplates thanks to palaeomagnetism and palaeobiostratigraphy (Scotese \& McKerrow, 1990; Franke et al., 2017 with references therein). The microplates are known as Avalonia and Armorica (Matte, 2001). They broke away from Gondwana during the early Palaeozoic, prior to docking against Baltica and Laurentia before the Devonian-Carboniferous collision (Matte, 2001). According to the two plates model, the European Variscan Belt is the result of the exclusive interaction of Gondwana and Laurentia-Baltica (Kroner \& Romer, 2013) and its complexity is the result of the distribution of crustal domains of contrasting rheological

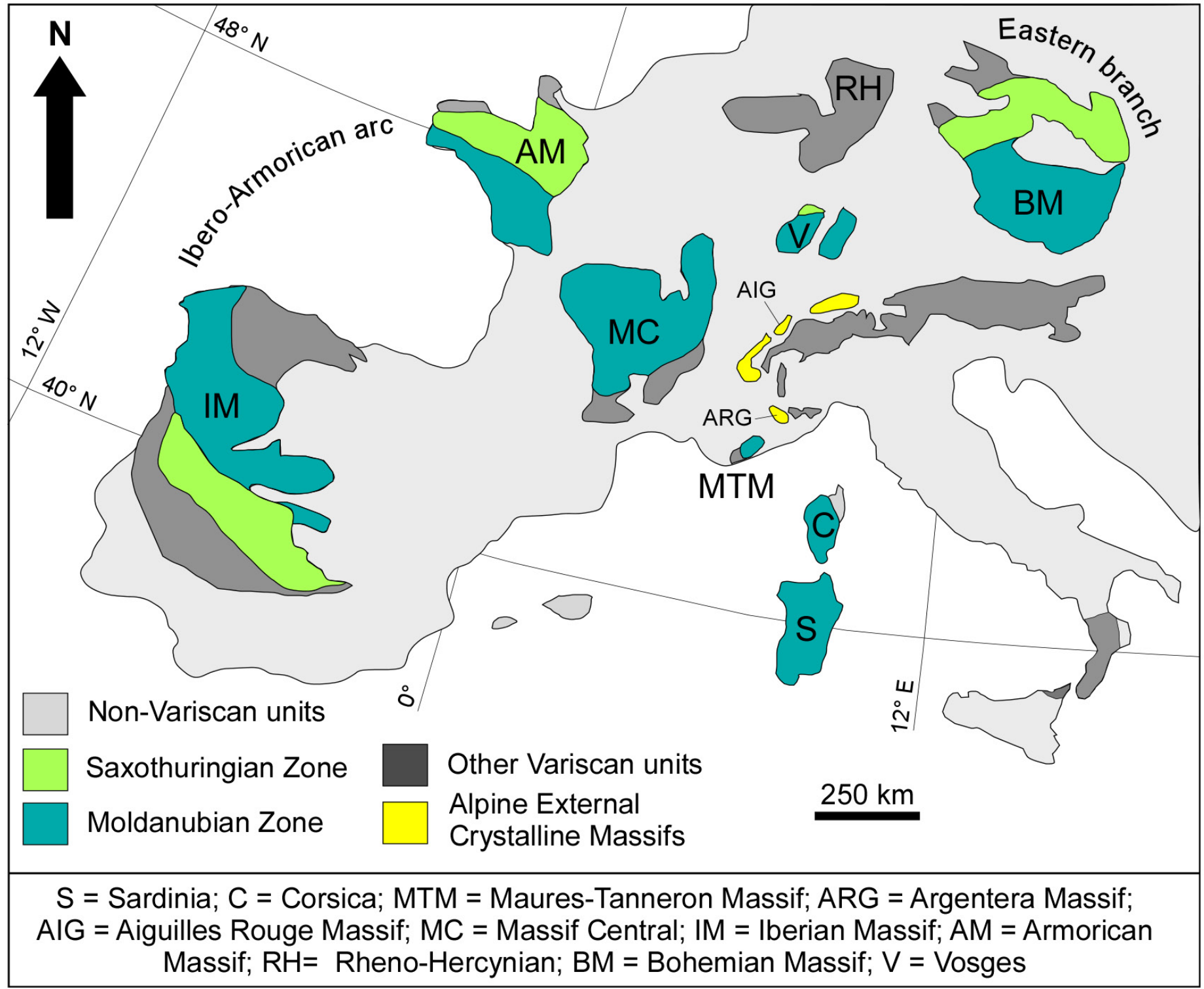

Fig. 1 - Present day distribution of the Variscan units in Europe (Modified after Compagnoni et al., 2010). 
properties. Despite the differences, both models consider the evolution of the belt characterized by indentation tectonics and transpressional deformation (Matte, 2001; García-Navarro \& Fernández, 2004; Pereira et al., 2008).

The portion of the Variscan Belt exposed in Central and Western Europe (Fig. 1) is known in the literature as the Variscides. This is the sector that recorded the longest tectonometamorphic history of the whole belt and is characterized by a composite orocline showing two large scale arcs (Matte, 2001): a western branch known as the Ibero-Armorican arc (Fig. 1; Dias \& Ribeiro, 1995; Matte, 2001; Dias et al., 2016; Fernández-Lozano et al., 2016) and a smaller eastern branch (Fig. 1; Matte, 2001; Bellot, 2005; Ballèvre et al., 2018; Simonetti et al., 2018, 2020a, 2020b).

The architecture of the Variscides is well defined (Fig. 1; Fluck et al., 1991; Matte, 2001; Faure et al., 2009; Skrzypek et al., 2012; Ballèvre et al., 2018): the Saxothuringian Zone (southwestern Iberian Massif, northern Armorican Massif, Vosges and Bohemian Massif) and the Moldanubian Zone (southern Iberian Massif, central and southern Vosges, Massif Central, southern Armorican Massif and southern Bohemian Massif) are recognized. The Moldanubian Zone is considered as the metamorphic root of the Variscan Belt (Schulmann et al., 2009).

The south-eastern sector of the Variscides underwent reworking and fragmentation during the Alpine orogenesis.

Key areas for understanding the evolution of the southern European Variscan Belt are the MauresTanneron Massif in southern France, the Corsica-Sardinia Block and the Alpine External Crystalline Massifs (Fig. 1). Some authors proposed that those sectors, that are now dispersed, were in lateral continuity during Variscan time and all were affected by a transpressive regional-scale shear zone known as East Variscan Shear Zone (EVSZ; Matte, 2001; Corsini \& Rolland, 2009; Carosi et al., 2012; Simonetti et al., 2018, 2020a).

\section{ANALYTICAL METHODS}

A systematic and multidisciplinary approach was used in the last years in order to investigate the regional scale shear zones described in this review. Here a description of the methods used for structural analysis and for petrochronology is presented.

Structural and microstructural analyses were all performed on oriented samples of sheared rocks cut along the $\mathrm{XZ}$ section of the finite strain ellipsoid. The kinematic of the flow, i.e. components of pure and simple shear acting simultaneously during the deformation (see Xypolias, 2010 and Fossen \& Cavalcante, 2017 for a review) was estimated using independent kinematic vorticity gauges: the C' shear band method (Fig. 2a; Kurz \& Northrup, 2008; Gillam et al., 2013), the stable porphyroclasts method (Fig. 2b; Passchier, 1987; Wallis et al., 1993) and the qauartz c-axis fabric (Fig. 2c; Wallis, 1995). Kinematic vorticity data were combined with a finite strain analysis, performed with the center-tocenter method (Fry, 1979), on the XZ section and, where possible, on the YZ section in order to obtain the shape of the 3D strain ellipsoid.

Quartz fabric, combined with the observed microstructures and the syn-tectonic mineral assemblages, have also been used to estimate the deformation temperature thanks to the opening angle thermometer (Kruhl, 1998; Law, 2014; Faleiros et al., 2016).

U-Th-Pb Petrochronological data (Fig. 2d) were obtained following the analytical procedure reported in Montomoli et al. (2013) and Braden et al. (2017). Monazite grains were selected taking into account their microstructural position, internal features and zoning revealed by X-Ray compositional maps (for $\mathrm{Y}, \mathrm{Ce}, \mathrm{Pr}$, $\mathrm{Th}, \mathrm{La}, \mathrm{P}, \mathrm{Ca}, \mathrm{U}$ ) and chemical analyses acquired with an electron microprobe (JEOL 8200 Super Probe hosted at the University of Milano, Italy) following the procedure given in Montomoli et al. (2013).

In metapelitic systems in wich monazite is associated with garnet (as observed in the studied mylonites), chemical proxies like $\mathrm{Y}+$ HREE zoning and REE patterns coupled with grain textural position and zoning are used to guide the interpretation of monazite ages with respect to the prograde and/or retrograde stages of metamorphism. This is possible thanks to the partition phenomena of those elements observed in the two phses (Engi et al., 2017; Iaccarino et al., 2017; Pyle et al., 2001; Pyle \& Spear, 1999; Williams et al., 2007). In particular garnet breakdown durign retro-metamorphism will release HREE and Y that can be preferentially sequestered by monazite. Grains were analyzed in situ by laser ablation inductively coupled plasma mass spectrometry (LA-ICP-MS) or by laser ablation split-stream (LASS; Kylander-Clark et al., 2013).

\section{ARGENTERA MASSIF: THE FERRIERE-MOLLIÈRES SHEAR ZONE}

The Argentera Massif is composed of the Gesso-SturaVésubie (GSV) and the Tinée (TMC) metamorphic complexes (Malaroda et al., 1970; Compagnoni et al., 2010) which are separated by the Ferriere-Mollières Shear Zone (FMSZ; Fig. 3a).

The GSV complex is made of migmatitic gneiss derived from Late Ordovician granitoids and migmatitic paragneiss. Within the migmatites, the small Frisson Lake layered mafic sequence (Ferrando et al., 2008; Rubatto et al., 2010 ) is recognized. The rocks of the GSV recorded a highpressure metamorphic peak followed by decompression down to high-temperature amphibolite-facies conditions and finally to low-temperature amphibolite-facies conditions. Migmatites are intruded by the Central granite (Fig. 3a) at $292 \pm 10 \mathrm{Ma}$ (Ferrara \& Malaroda, 1969) and by other minor granitic bodies such as the Valle Stura Leuocogranite (Fig. 3a)

The TMC complex is made of migmatites formed at the expense of metasediments (Compagnoni et al., 2010). Eclogite relicts are reported by Faure-Muret (1955), Malaroda et al. (1970) and recently by Jouffray et al. (2020) that interpreted those rocks as a dismembered cryptic suture zone. According to Compagnoni et al. (2010) migmatites of the TMC present a smaller proportion of leucosomes than the migmatites of the GSV complex suggesting a smaller amount of melting.

The FMSZ strikes NW-SE and extends for about 20 $\mathrm{km}$ with a thickness between $100 \mathrm{~m}$ to the south-east and more than $1000 \mathrm{~m}$ to the north-west. The fault rocks in the FMSZ resulted from the shearing of migmatites of the GSV and the TMC. The transition from non-sheared migmatites to protomylonites, mylonites and ultramylonites can be observed along a gradient of increasing deformation traced 

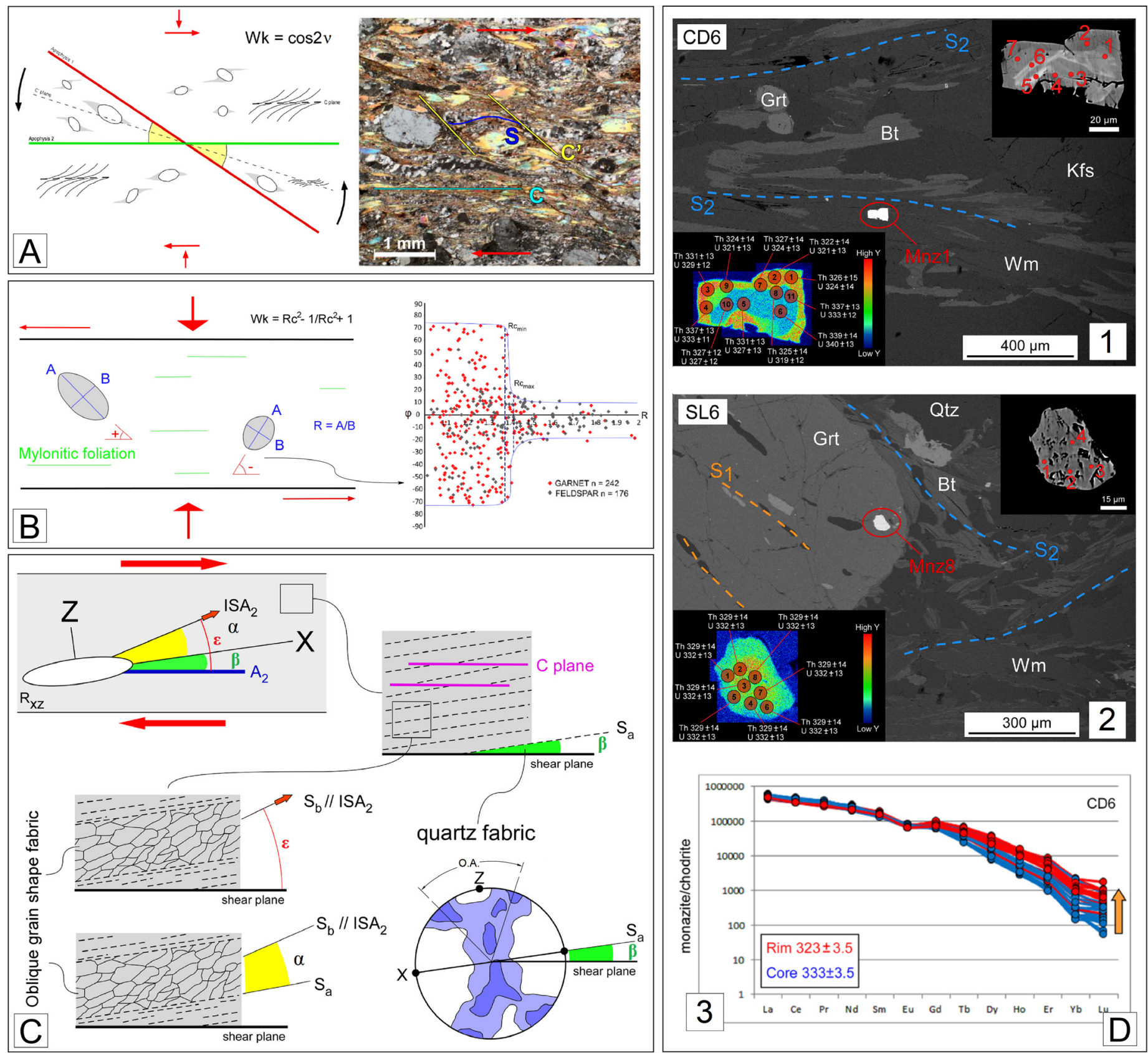

Fig. 2 - Sketch summarizing the main used methodologies for structural and pretrochronological analysis. A) Left: schematic diagram of possible microstructures developed under general flow conditions in a mylonite with dextral sense of shear and their appearance in thin section (modified after Simonetti et al., 2018). The flow apophyses A1 and A2 are indicated in red and green, respectively. The angle $2 v$ between the two apophyses (yellow) is bisected by the C' shear plane (dotted line). The equation to calculate Wk is also shown (modified after Kurz \& Northrup, 2008). Right: micrograph (crossed polars) showing C' planes in mylonite of the FMSZ (the short and the long borders of the micrograph are parallel to $\mathrm{Z}$ and $\mathrm{X}$ axes of the finite strain ellipsoid, respectively); B) Schematic illustration of stable porphyroclasts method (Wallis et al., 1993) for vorticity analysis, $\mathrm{R}$ = axial ratio of porphyroclasts, $\phi=$ orientation of long axis of porphyroclasts respect to foliation, $\mathrm{Rc}_{\min }$ and $\mathrm{Rc}_{\max }$ are the minimum and maximum critical axial ratios respectively (modified after Simonetti et al., 2020b); C) Schematic illustration of quartz c-axis method for vorticity analysis (modified after Xypolias, 2010); A2 = flow apophysis 2; ISA2 = istantaneous stratching axis 2; Sa = macroscopic foliation; $\mathrm{Sb}=$ quartz oblique foliation; $\alpha=$ angle between ISA2 and $\mathrm{x}$ axis of finite strain; $\beta=$ angle between $\mathrm{x}$ axis of finite strain and flow apophysis $2 ; \varepsilon=$ angle between ISA2 and flow apophysis 2; D) example of petrochronological study of mylonitic samples of the Cavalaire Fault (modified after Simonetti et al., 2020b): 1 = monazite grain located along the mylonitic foliation; 2 = monazite grain included in garnet porphyroclast; 3 = example of chondrite normalized (based on values of McDonough \& Sun 1995) REE pattern of dated monazites in sample CD6 from the Cavalaire Fault.

towards the center of the shear zone (Fig. 3b; Carosi et al., 2016; Simonetti et al., 2017, 2018, 2021a, 2021c).

Mylonitic foliation is subvertical and oriented NWSE with a mineral lineation plunging at low angle toward the NNW (Fig. 3b). Kinematic indicators, such as S-C' fabric (Fig. 4a, b), micafish, mantled porphyroclasts and quartz oblique foliation, indicate a strike-slip component of movement with a minor reverse, top-tothe-SSE sense of shear (Carosi et al., 2016; Simonetti et al., 2018, 2021c). 


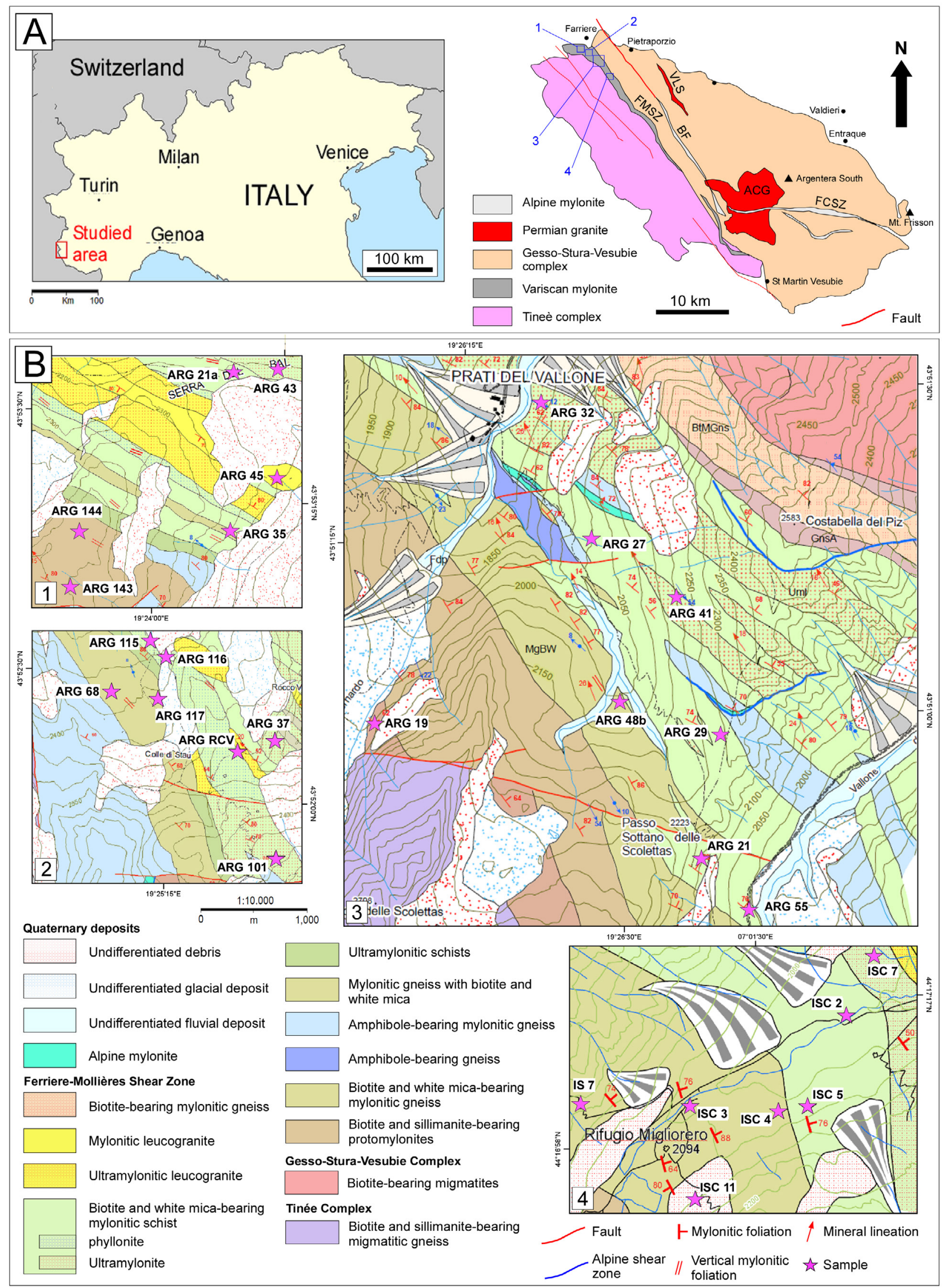

Fig. 3 - A) location of the study area and geological sketch map of the Argentera Massifs (modified after Compagnoni et al., 2010; Simonetti et al., 2018); B) Detailed geological maps and sampling locations of the FMSZ (modified after Carosi et al., 2016; Simonetti et al., 2021a, 2021c): 1) Serra del Ball area in the Ferriere Valley; 2) Colle di Stau area; 3) Prati del Vallone area in the Pontebernardo Valley; 4) Rifugio Migliorero area in the Ischiator Valley. 

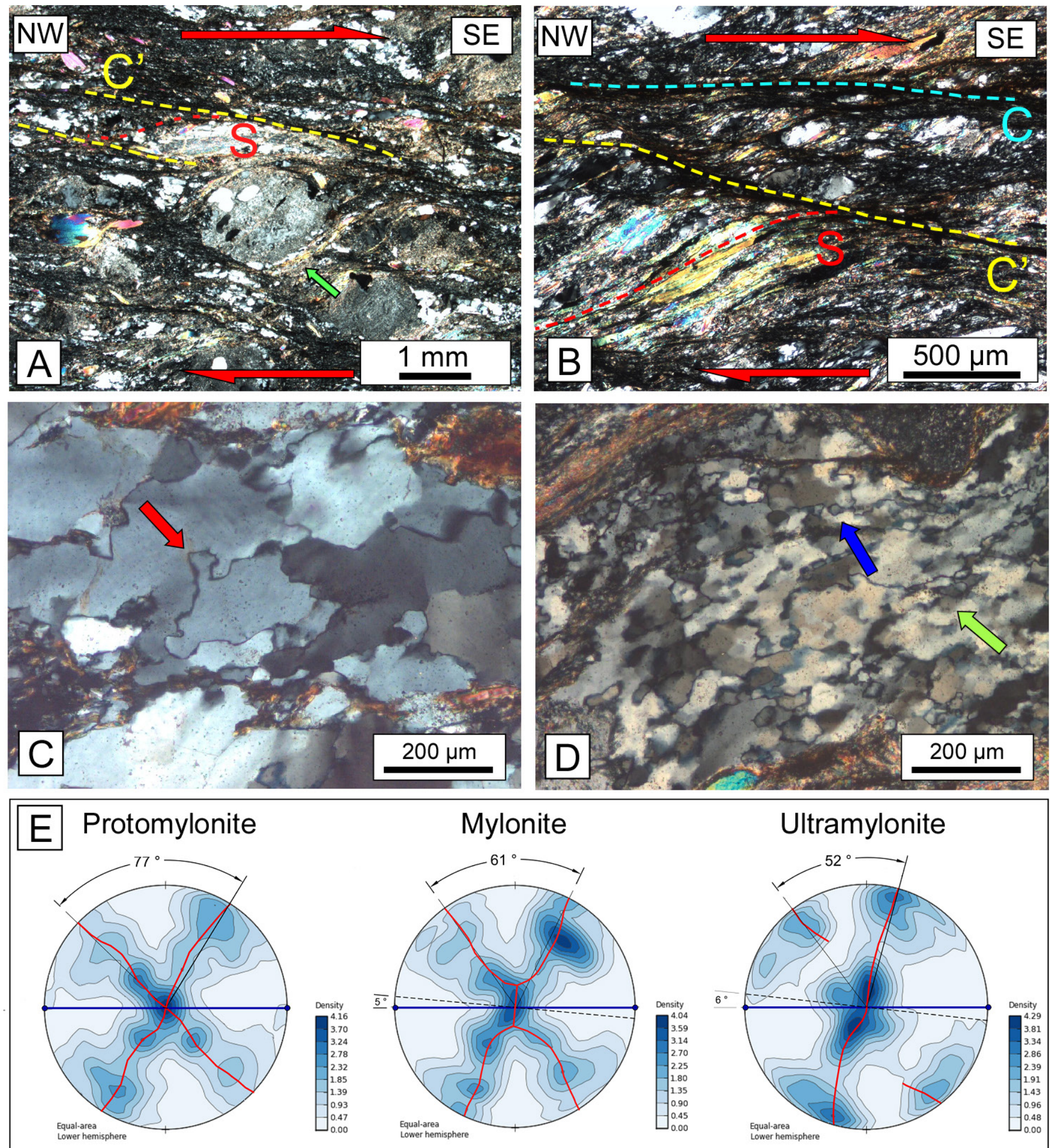

Fig. 4 - A) mylonite at the microscale: S-C' fabric and white mica quarter mats (green arrow) around a feldspar porphyroclast, sense of shear is top-to-the SE (crossed nicols); B) continous cleavage and S-C-C' fabric in the ultramylonite indicating a top-to-the SE sense of shear (crossed nicols); C) quartz in a protomylonite with large grain size and lobed boundaries (red arrow) indicative of grain boundary migration; D) quartz dynamically recrystallized by subgrain rotation recrystallization in a mylonite, subgrains (green arrow) and new grains (blue arrow) can be recognized; E) examples of optically measured quartz c-axis fabrics (equal-area lower-hemisphere projections) for protomylonite, mylonite and ultramylonite (modified after Simonetti et al., 2021c). All pole figures are oriented perpendicular to the foliation and parallel to the lineation. Dashed line is the shear plane; blue line is the main foliation and blue dots are the mineral lineation. Fabric asymmetries indicate a dextral topto-the-SE sense of shear. Opening angle and angle between the main foliation and the shear plane are reported. 
Quartz microstructures (Piazolo \& Passchier, 2002; Stipp et al., 2002) are indicative of grain boundary migration (Fig. 4c) partially overprinted by subgrain rotation recrystallization in mylonites (Fig. 4d) and ultramylonites. The opening angles of c-axis fabrics (Fig. 4e; Kruhl, 1998; Law, 2014; Faleiros et al., 2016) revealed a temperature of deformation between $610{ }^{\circ} \mathrm{C}-588{ }^{\circ} \mathrm{C}$ for the protomylonites, $538{ }^{\circ} \mathrm{C}-482{ }^{\circ} \mathrm{C}$ for the mylonites and $500{ }^{\circ} \mathrm{C}-418^{\circ} \mathrm{C}$ for the ultramylonites in good agreement with the observed transition from amphibolite-facies to greenschist-facies syn-tectonic mineral assemblage along the deformation gradient (Simonetti et al., 2021c).

Kinematic vorticity analysis allowed to recognize a transpressional deformation regime characterized by a non-coaxial flow with a prevalent component of pure shear acting together with simple shear, the latter incresing along the observed deformation gradient. Finite strain analysis yields average shortening and stretching values of $27 \%$ and $36 \%$, measured parallel to the inferred flow plane (shear zone boundaries) and flow direction, respectively (Simonetti et al., 2018).

Deformation ages were obtained thanks to $\mathrm{U}-\mathrm{Th}-\mathrm{Pb}$ monazite petrochronology on grains collected along the deformation gradient. The ${ }^{206} \mathrm{~Pb} /{ }^{238} \mathrm{U}$ and ${ }^{208} \mathrm{~Pb} /{ }^{232} \mathrm{Th}$ ages range mainly from $\sim 340 \mathrm{Ma}$ to $\sim 320 \mathrm{Ma}$ (Simonetti et al., $2018,2021 \mathrm{c})$. The oldest ages of this range were obtained in high-Y monazites along the protomylonitic foliation close to the margin of the shear zone and in asymmetric high-Y monazite rims in the same rocks. Younger ages ( 320 Ma) were obtained from monazite grains along the mylonitic foliation in the core of the shear zone. This broad correlation between ages and deformation gradient suggests a progressive concentration of deformation into the center of the shear zone. This approach revealed long lasting activity on the FMSZ that continued for 20 million years under progressively temperature decreasing.

\section{AIGUILLES ROUGE MASSIF: THE EMOSSON-BERARD SHEAR ZONE}

In the Aiguilles Rouge Massif (Fig. 5a), in the Emosson Lake area (Fig. 5b) and along its SW extension the Val Berard area (Fig. 5c), rocks are strongly sheared along a thick belt of mylonites (Von Raumer \& Bussy, 2004) known as Emosson-Berard Shear Zone (Fig. 5; Simonetti et al., 2020a). Alpine deformation here is very weak and only developed under brittle conditions (Dobmeier \& Raumer, 1995). Mylonites are made at the expense of paragneiss, micaschist and orthogneiss. Partial melting within the shear zone is recognized and described by Von Raumer \& Bussy (2004) and Genier et al. (2008).

The main foliation strikes NE-SW and is always subvertical with a mineral lineation plunging gently toward the NE (Fig. 5b, c). Kinematic indicators such as -type porphyroclasts (Fig. 6a), S-C and S-C' fabric (Fig. 6b) and micafish indicate a dextral top-to-the-SW sense of subhorizontal shear (Von Raumer \& Bussy, 2004; Simonetti et al., 2020a).

In all sheared rocks, quartz is generally coarse-grained with lobate boundaries (Fig. 6c) and locally window and pinning structures are present and are indicative of grain boundary migraton. In some cases an incipient subgrain rotation recrystallization overprinting higher temperature microstrucrures can be recognized (Fig. 6d). These quartz microstructures indicate that grain boundary migration is the dominant mechanism for dynamic recrystallization. In good agreement with the observed microstructures, measured c-axis fabric opening angles (Fig. 6e) are indicative of moderately high-temperature deformation conditions ranging from $\sim 550{ }^{\circ} \mathrm{C}$ to $\sim 630{ }^{\circ} \mathrm{C}$ (Simonetti et al., 2020a).

Kinematic vorticity analyses allow to define the flow regime of the EBSZ, obtained data indicate a pure shear-dominated transpression (Simonetti et al., 2020a). The amount of pure shear and simple shear measured in the different sheared rocks is variable: orthogneiss always record a larger component of pure shear than the metasedimentary rocks. This is indicative of a partitioning of the deformation between the two lithotypes that is probably controlled by the difference in their rheological properties.

$\mathrm{U}-\mathrm{Th}-\mathrm{Pb}$ dating was performed in situ on monazite grains within samples collected in the shear zone. Two groups of monazites are recognized: a first group composed of grains included in garnet or biotite porphyroclasts and a second group composed of grains within the main foliation.

Th- $\mathrm{Pb}$ ages ranges from $\sim 333 \pm 5 \mathrm{Ma}$ to $\sim 319 \pm 3 \mathrm{Ma}$ while U-Pb ages ranges from $\sim 329 \pm 13 \mathrm{Ma}$ to $\sim 318 \pm 7$ Ma (Simonetti et al., 2020a). Older ages of $\sim 340-330 \mathrm{Ma}$ were obtained from low-Y cores or from grains included in porphyroclasts and represent monazite growth during prograde metamorphism under near peak amphibolitefacies conditions. Younger ages of $\sim 320-310 \mathrm{Ma}$ are recorded in syn-tectonic high-Y monazite grains along the mylonitic foliation and are representative of the onset of transpressional deformation along the EBSZ.

\section{MAURES MASSIF: THE CAVALAIRE FAULT}

The Maures Massif (Fig. 7a) is the southernmost segment of the Variscan Belt in France (Matte, 2001; Bellot, 2005). It is composed of low- to high-grade metamorphic rocks (Fig. 7a), the latter intruded by Carboniferous granitoids. Low- and medium-grade rocks belong to the External Zone while high-grade rocks belong to the Internal Zone (Fig. 7a).

The contact between the two zones is marked by a kmscale shear zone known as Cavalaire Fault (CF, Fig. 7b; Schneider et al., 2014; Oliot et al., 2015; Gerbault et al., 2016; Simonetti et al., 2020b).

The CF, as testified by field observations, is characterized by a NE-SW trending km-thick high-strain zone (Simonetti et al., 2020b), involving biotite-kyanite and biotite-muscovite-sillimanite zones. West of the $\mathrm{CF}$ unsheared gneiss and micaschist of the External Zone are present, whereas migmatites of the Internal Zone crop out on the eastern side (Fig. 7b).

Mylonitic foliation dips to the NW, with a mineral lineation materialized by biotite and/or staurolite, trending NW-SE and plunging to the NW (Fig. 7b). Asymmetric strain fringes around porphyroclasts (Fig. 8a) and C-S fabrics (Fig. 8b) indicate a top-to-the-NW sense of shear.

Quartz grains have lobate grain boundaries (Fig. 8c) and pinning microstructures can be recognized (Fig. 8d). Those features suggest a dynamic recrystallization by 

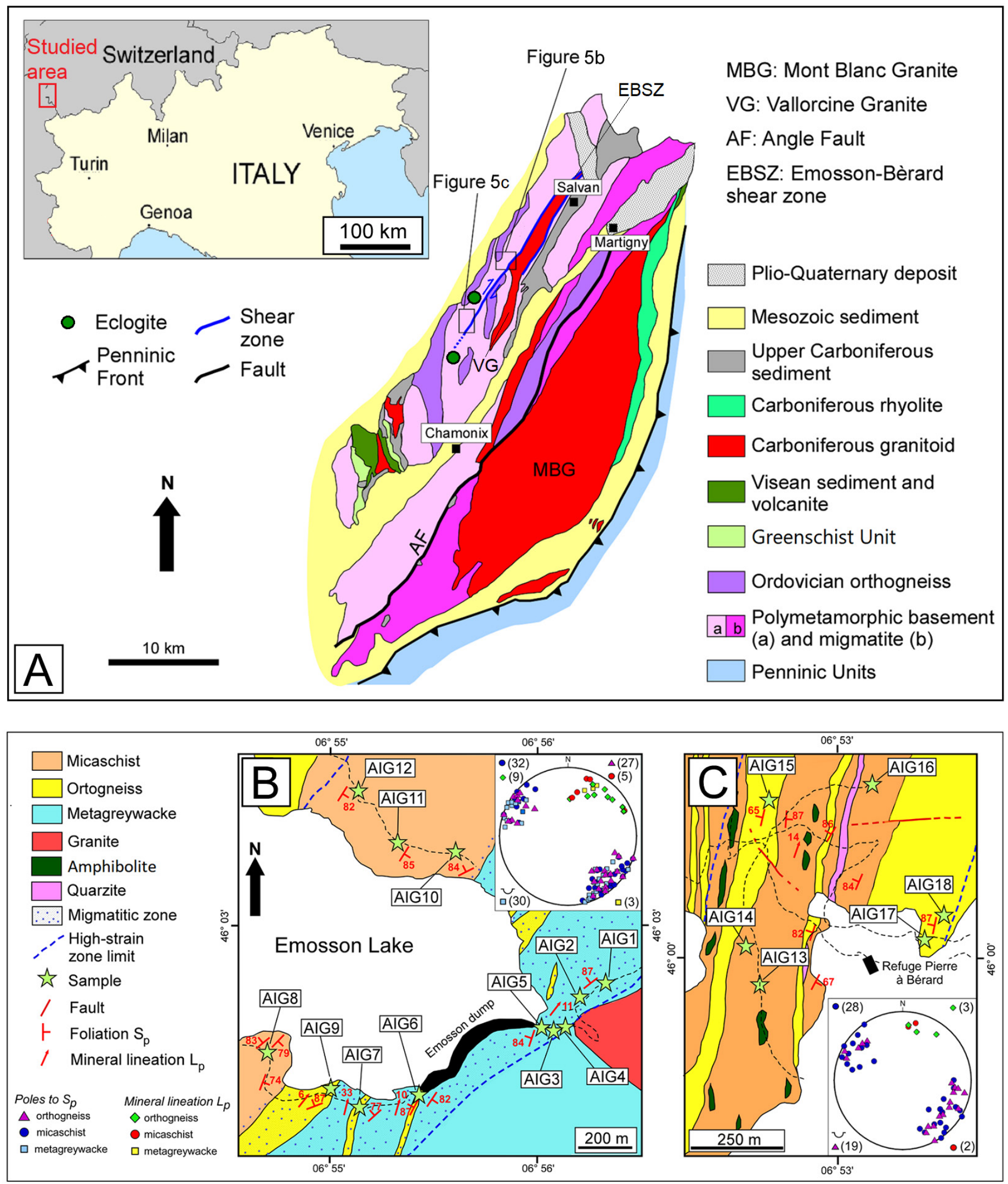

Fig. 5 - A) location of the study area and geological sketch map of the Aiguilles Rouges Massif (modified after Compagnoni et al., 2010); B) Geological sketch map of the Emosson Lake area (modified after Von Raumer \& Bussy, 2004; Simonetti et al., 2020a) and sample location; C) Geological sketch map of the Val Bèrard area (modified after Von Raumer \& Bussy, 2004; Simonetti et al., 2020a) and sample location. 

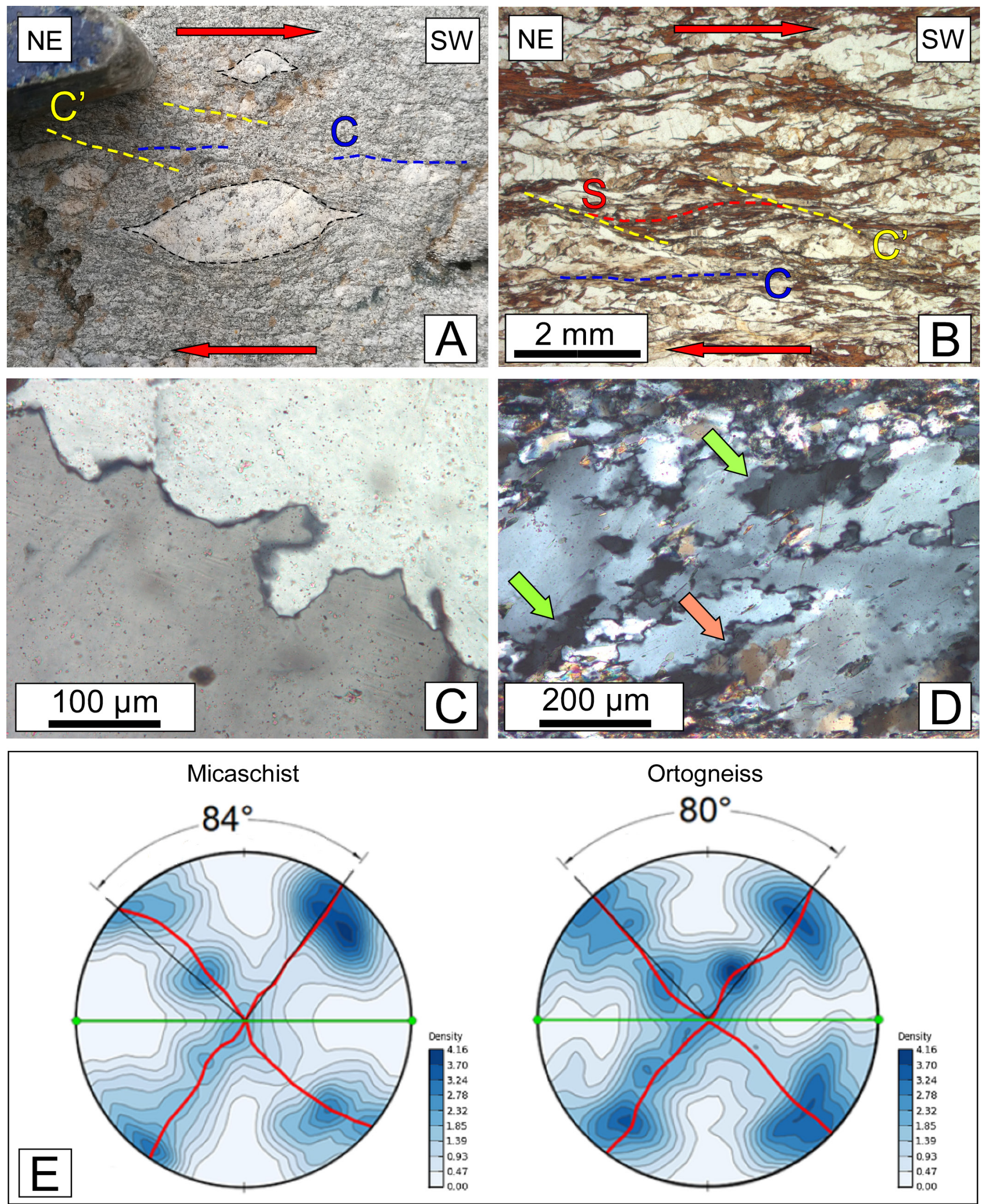

Fig. 6 - A) S-C-C' fabric and $\sigma$-type K-feldspar porphyroclast at the outcrop scale in the orthogneiss of the Val Bèrard area; B) S-C-C' fabric in the micaschist in thin section (parallel nicols); C) detail of a quartz grain showing a lobate boundary; D) quartz subgrains (green arrow) and small new grains (pink arrow) around older coarse grains; E) examples of optically measured quartz c-axis fabrics (equal-area lower-hemisphere projections) for a sheared micaschist and ortogneiss (modified after Simonetti et al., 2020a). 

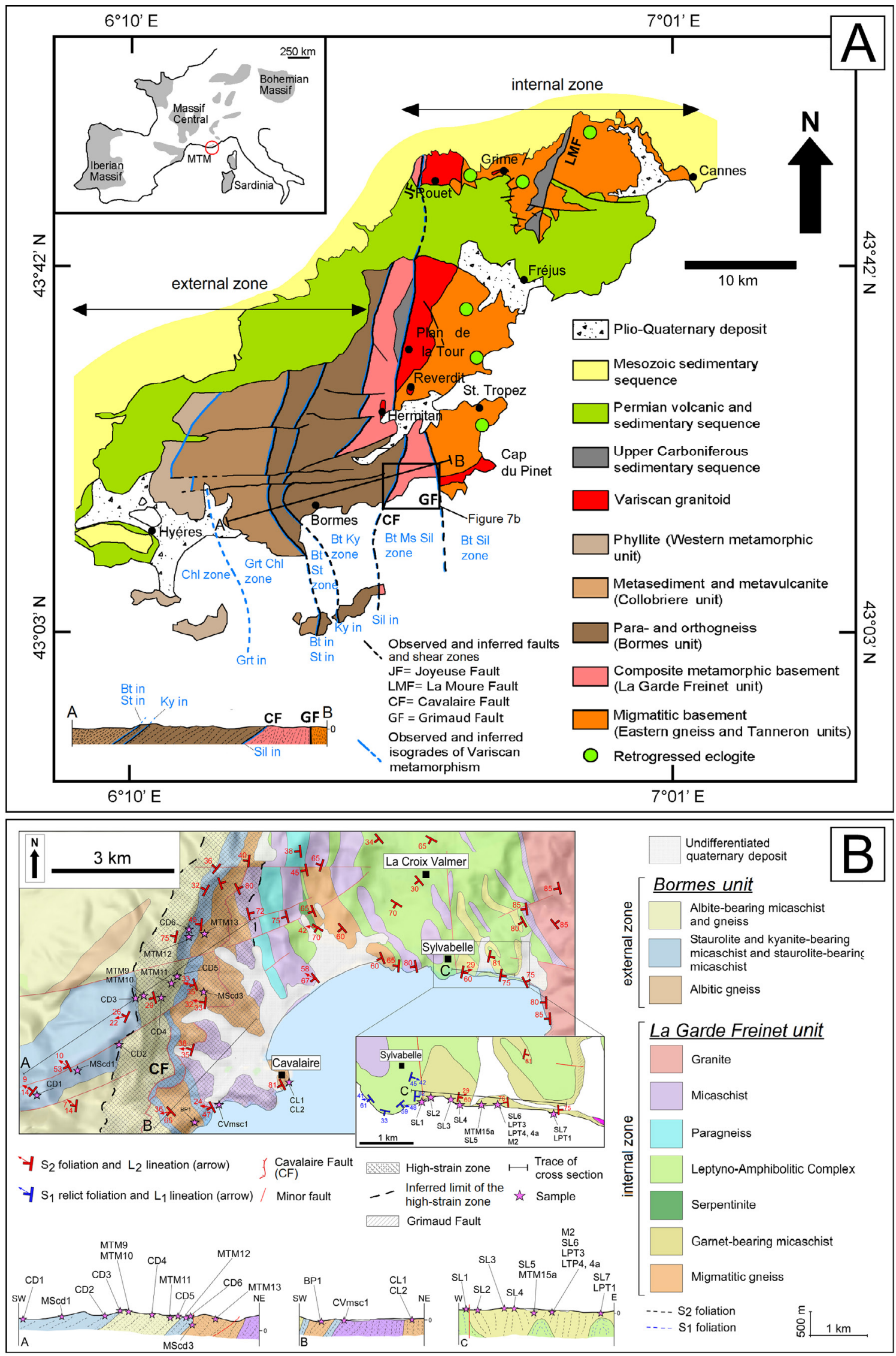

Fig. 7 - A) Geological and structural sketch map of the Variscan basement of the Maures-Tanneron Massif, metamorphic zonation is reported (modified after Compagnoni et al., 2010; Schneider et al., 2014; Oliot et al., 2015; Simonetti et al., 2020b); B) geological sketch map of the study area with samples locations, geological cross sections, samples positions are also reported (modified after Simonetti et al., 2020b). 

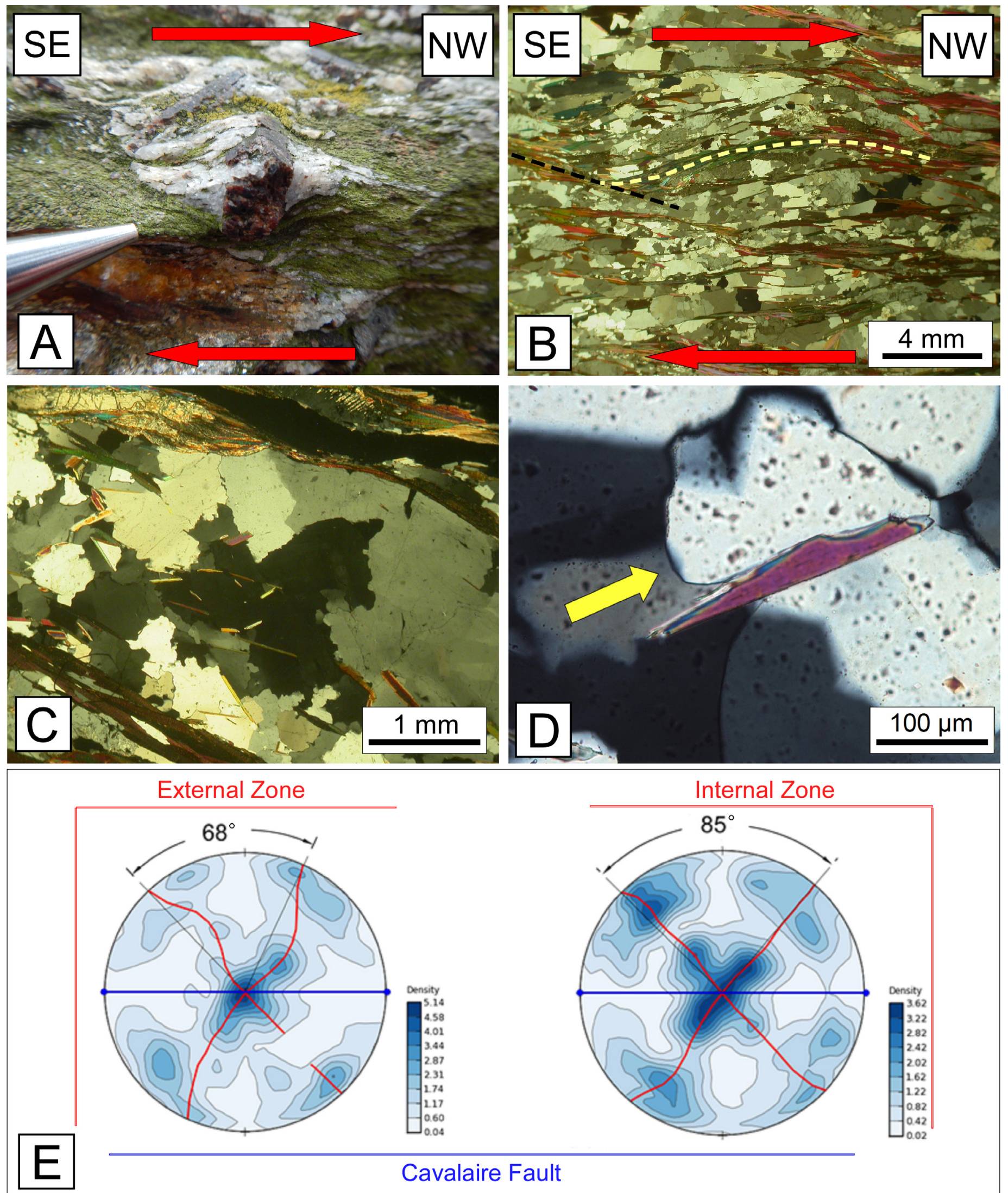

Cavalaire Fault

Fig. 8 - A) Asymmetric quartz strain fringes around a staurolite porphyroclast in staurolite-bearing micaschist showing a top-to-the-NW sense of shear; B) S-C' fabric in the mylonitic gneiss of the Cavalaire Fault showing a top-to-the-NW sense of shear (C' is marked by a black dashed line, S plane is marked by a yellow dashed line); C) coarse-grained quartz crystals with lobate grain boundaries; D) pinning structure (yellow arrow); E) examples of optically measured quartz c-axis fabrics (equal-area lower-hemisphere projections) for two samples of the Cavalaire Fault (Simonetti et al., 2021b). 
grain boundary migration under a temperature range between $500{ }^{\circ} \mathrm{C}$ and $700{ }^{\circ} \mathrm{C}$. Quartz fabric analysis (Fig. 8e) confirms this temperature range, in particular the opening angle thermometer gives temperatures between $\sim 520{ }^{\circ} \mathrm{C}$ and $\sim 630{ }^{\circ} \mathrm{C}$ (Simonetti et al., 2021b).

Kinematic vorticity analyses revealed a transpressional deformation along the $\mathrm{CF}$ occurred under general shear condition with a major component of pure shear acting together with simple shear (Simonetti et al., 2020b).

Finite strain data (Simonetti et al., 2020b) suggest a general flattening deformation, in agreement with a pure shear-dominated transpression (Fossen \& Tikoff, 1993; Fossen et al., 1994; Fossen, 2016), this is also supported by field evidences such as the presence of boudinage along both $\mathrm{XZ}$ and $\mathrm{YZ}$ sections of finite strain ellipsoid.

Age of deformation along the $\mathrm{CF}$ was obtained thanks to U-Th-Pb in situ monazite petrochronology (Simonetti et al., 2020b). Microstructural position, texture, zoning and chemical analyses, highlight a complex history of monazite growth during the tectono-metamorphic history: a first generation of monazite grew during prograde metamorphic conditions while a second group of monazite grew during retrogression coupled with transpressonal deformation. Ages from the syn-tectonic monazite grains indicate active deformation at $\sim 323 \mathrm{Ma}$. Older ages range between $\sim 340$ $\mathrm{Ma}$ and $333 \mathrm{Ma}$ and are in agreement with the timing of the prograde metamorphism developed during collisional stage before transpression (Oliot et al., 2015).

\section{DISCUSSION}

In the last years several new data were collected from some of the main shear zones in the variscan fragments of the Mediterranean area (the EBSZ in the Aiguilles Rouge Massif, the FMSZ in the Argentera Massif and the CF in the Maures Massif). The systematic and multidiscplinary study of such structures allowed to better undestrand their tectono-metamorphic evolution and their role in the frame of the Southern European Variscan Belt.

The shear zones in the Argentera (FMSZ), Aiguilles Rouges (EBSZ) and Maures Massifs (CF) present striking similar features from the structural, geochronological and petrological point of view. Together with the PosadaAsinara shear zone in northern Sardinia (Carosi \& Palmeri 2002; Cruciani et al., 2015; Carosi et al., 2020), they are all transpressional shear zones with an important component of pure shear acting together with simple shear (Fig. 9).

The simple shear component increases across the shear zones in northern Sardinia (Carosi et al., 2009; Carosi \& Palmeri, 2002; Graziani et al., 2020) and in the Argentera Massif (Simonettiet al., 2018). Differently, in the Aiguilles Rouge Massif and in the Maures Massif this temporal variation in vorticity of flow was not recognized probably because of the spatial partitioning of flow due to different rheology of the involved rocks (Simonetti et al., 2020a).

The studied shear zones share a common tectonic evolution, in the same time interval (Fig. 9), characterized by initiation under high temperature amphibolite-facies

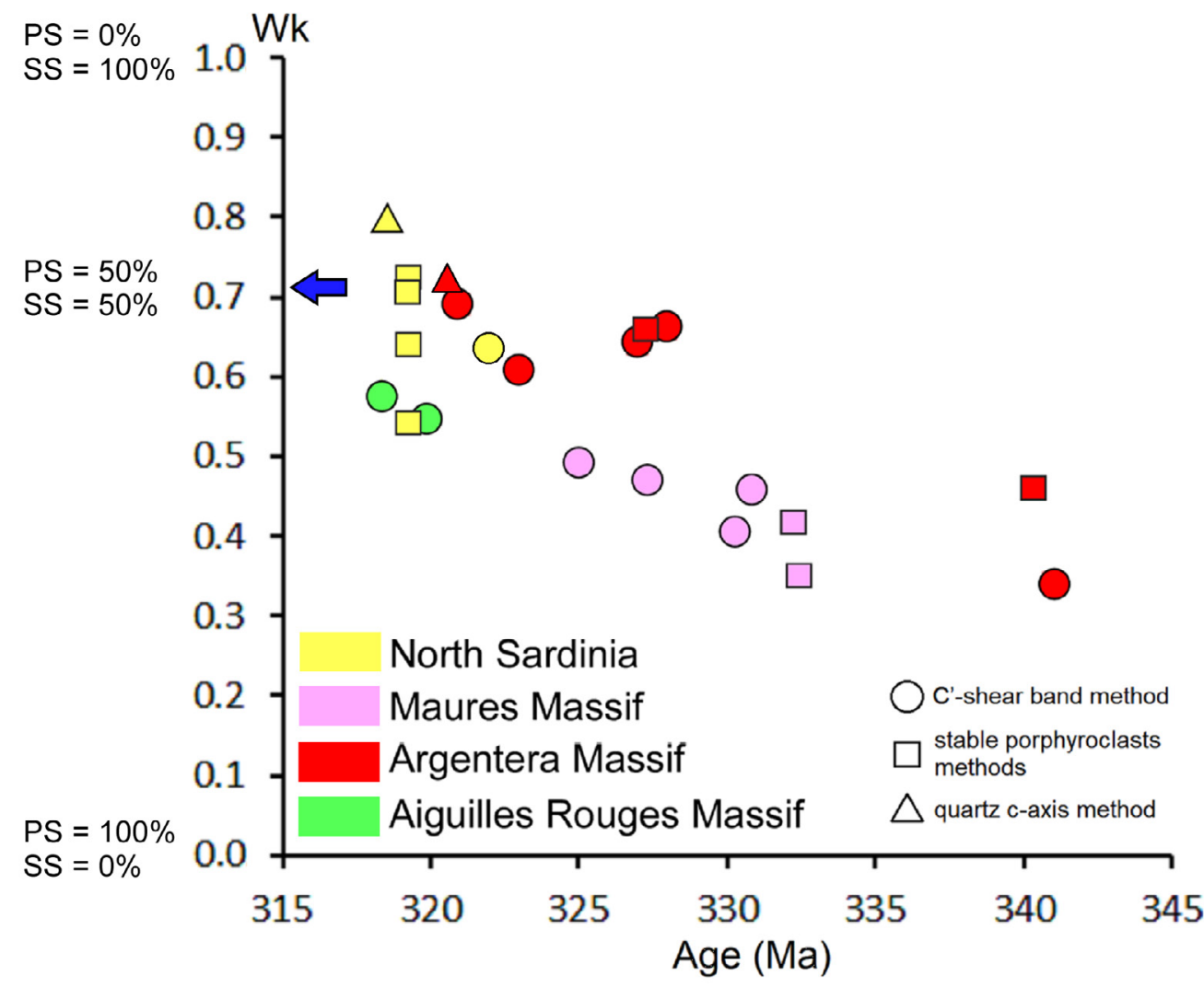

Fig. 9 - Relation between vorticity number and age in the Argentera Massif (Simonetti et al. 2017, 2018, 2021c), in the Aiguilles Rouge Massif (Simonetti et al., 2020a), in the Maures Massif (Simonetti et al., 2020b) and in northern Sardinia (Carosi \& Palmeri, 2002; Frassi et al., 2009; Carosi et al., 2012, 2020). All data are represented together with the age obtained from the same sample. 


\section{late Carboniferous}

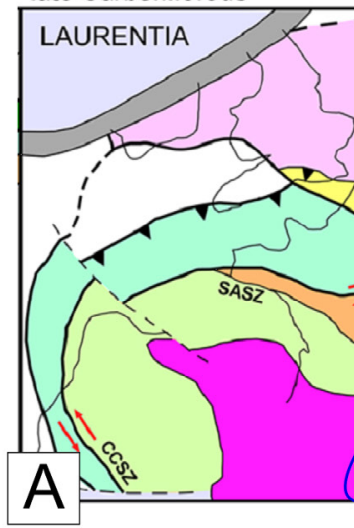

Sense of shear of major shear zones
Saxo-Thuringian zone Rheno-Hercynian zone Armorican zone Moldanubian zone Southern Variscides schistose nappes

Carboniferous basin CCSZ $=$ Coimbra-Cordoba shear zone

SASZ = South Armorica shear zone

East Variscan Shear Zone (EVSZ)

Variscan granite

High-grade metamorphic complex (internal zone)

Low- to mdium-grade metamorphic complex (external zone)

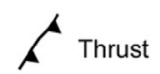

A
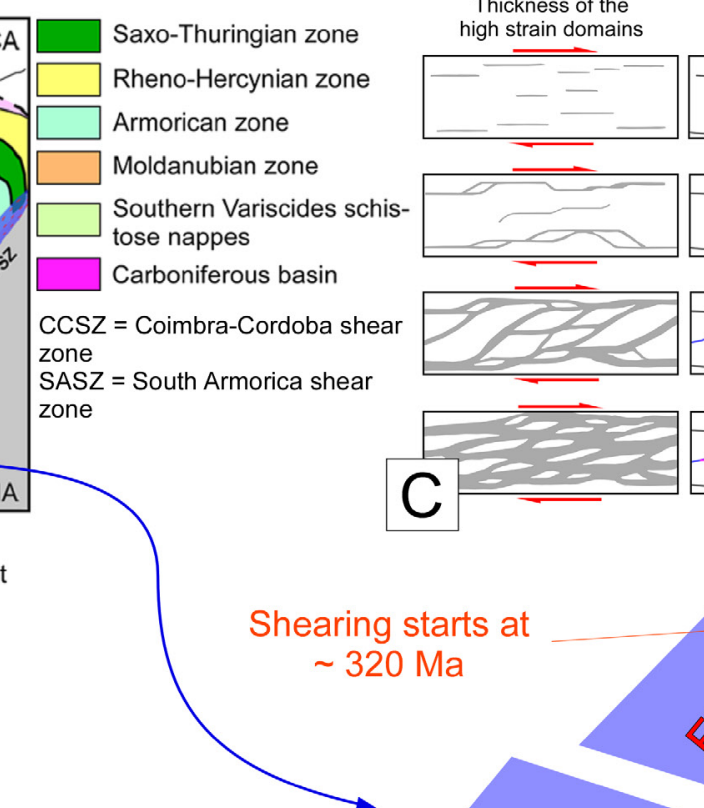

Age of activation

Old
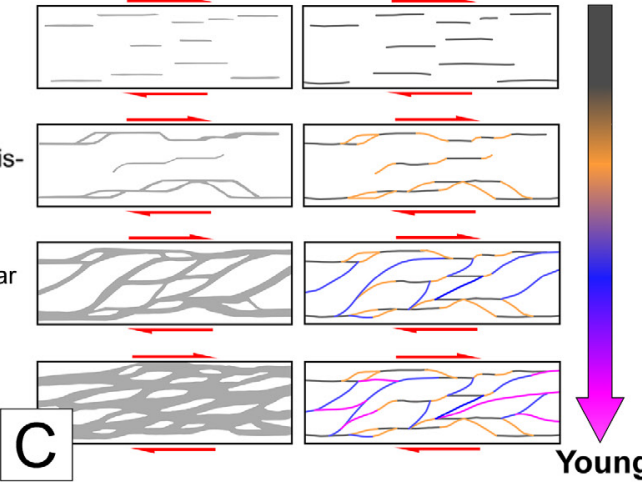

Cropping-out EVSZ branch

i Interpreted EVSZ branch

AIG = Aiguilles Rouge Massif

$\mathrm{AR}=$ Argentera Massif

MTM = Maures-Tanneron Massif

$\mathrm{SA}=$ Sardinia

$\mathrm{CO}=$ Corsica

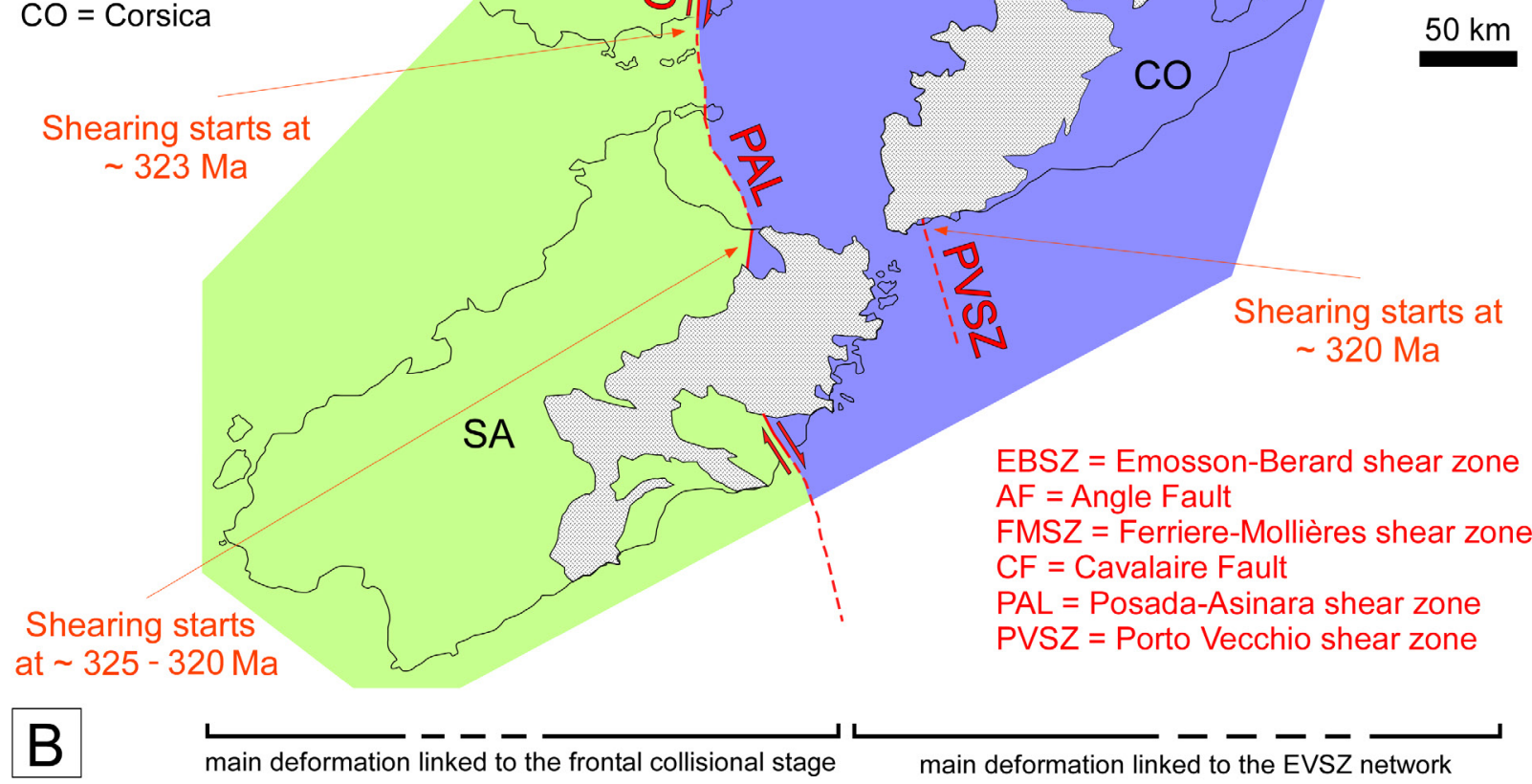

Fig. 10 - A) Simplified sketch map of the European Variscides during late Carboniferous (modified after Guillot \& Ménot, 2009; Carosi et al., 2012; Simonetti et al., 2018); B) Detail of the inferred lateral relationship between the Corsica-Sardinia block, the Maures-Tanneron Massif, the Argentera Massif and the Aiguilles Rouges Massif (Simonetti et al., 2020a). The main active shear zones are reported. Ages for of the onset of transpression are from: Simonetti et al. (2018, 2021c) for the Argentera Massif; Simonetti et al. (2020a) for the Aiguilles Rouge Massif; Simonetti et al. (2020b) for the Maures-Tanneron Massif; Carosi et al. $(2012,2020)$ for the northern Sardinia; C) Simplified sketch representing the evolution of a system of dextral shear zones based on progressive structural growth assumed in the fault linkage model (Trudgill \& Cartwright, 1994; Dawers \& Anders, 1995; Walsh et al., 2002, 2003; Soliva \& Benedicto, 2004; Soliva et al., 2006; Fossen \& Cavalcante, 2017). Left column: evolution of proportion of high strain domains within the shear zone over time; right column: different colors represent the age of activation of the braches. 
conditions and progressive temperature decrease down to greenschist-facies in some cases.

Taking into account the position of the studied sectors, if they are restored to their original orientation during Variscan times (Fig. 10a), and the kinematics and features of the studied shear zones, they can readily be interpreted as interconnected structures belonging to the same network of dextral shear zones belonging to the EVSZ (Fig. 10b; Corsini \& Rolland, 2009; Carosi et al., 2012; Schneider et al., 2014; Simonetti et al., 2020a). Despite some exceptions, a general increase in the component of simple shear during time, at the scale of the whole EVSZ, can be recognized by comparing vorticity data and ages of the different branches (Fig. 9). This can reflect a change in the stress field at the continent-scale due to a change in the relative convergence angle between the plates over time and/or to rotation of the active structures within the network during ongoing collision.

The results obtained in the last years support and strengthen, with new structural and geochronological data, the model proposed by Rollet et al. (2002), Rosenbaum et al. (2002) and Advokaat et al. (2014) of the CorsicaSardinia Block connected to southern France in continuity with the Western Alps and located along a major regional scale transpressive shear zone.

Despite the similarities, the preserved branches of the EVSZ have slightly different ages (Fig. 10b). This can be explained by their progressive growth using a tectonic linkage model (Fig. 10c; Trudgill \& Cartwright, 1994; Dawers \& Anders, 1995; Walsh et al., 2002, 2003; Soliva \& Benedicto, 2004; Soliva et al., 2006; Fossen \& Cavalcante, 2017). Shear zones within the network grow in length as they accumulate displacement, and tend to connect with adjacent structures to form composite systems and networks. It is therefore possible to recognize older branches that record a longer deformation history and younger branches that record a shorter history.

It should be noted that the older branches, such as the Ferriere-Mollières Shear Zone in the Argentera Massif, unlike the younger ones, such as the shear zones in the Maures-Tanneron Massif, Aiguilles Rouges and northern Sardinia, developed fully within migmatitic crust. Variscan transpression is considered to be synchronous with anatexis, or to have initiate shortly after anatexis (Genier et al., 2008; Padovano et al., 2012, 2014; Simonetti et al., 2018, 2020a). It is therefore possible that transpressional deformation along the EVSZ preferentially started to be accomodated in the lower crust which was easier to deform because of the ongoing anatexis, and later migrated into the non-migmatitic crust.

Since all the branches of the EVSZ developed in a transpressional regime it is possible to hypothesize that they have favored the exhumation of the deep crust in the core of the network during transpression. The result is that some shear zones, especially those in a more marginal position within the network, juxtapose domains with different metamorphic imprint. These cases can be represented by the Cavalaire Fault in the Maures Massif or by the Posada Asinara shear zone in Sardinia. In this context the future Alpine External Crystalline Massifs should be regarded as being representative of the sheared and exhumed deep crust in the core of the EVSZ network.

The transpressional deformation regime, the high temperature of deformation and the late-Carboniferous age of shearing that characterize the fragments of the EVSZ, all suggest that its activity is not related to the post-Variscan deformation and to a transition from Pangea B to Pangea A. The available data, demonstrate that, at least in the studied sectors there is no geological and structural evidence that supports the dextral movement of Gondwana in Early Permian time since the observed shear zones were all related to late variscan transpression. If this process ever occurred, the structural evidences must be recognized elsewere.

Further studies are needed to recognize other potential sectors of the southern European Variscan Belt affected by branches of the EVSZ in order to better constrain the lateral extent of this system of shear zones. This would allow to formulate a more detailed model for its evolution, and to better understand how the presence of this regional-scale discontinuity influenced post-Variscan tectonic evolution of western Europe

\section{CONCLUSIONS}

The data obtained in the last years allows to establish that, during Variscan time, the Argentera Massif, the Aiguilles Rouges Massif and the Maures Massif were all affected by pure-shear dominated transpression that started at 340-330 Ma under high-temperature conditions and continued during retrograde metamorphism. All those sectors, together with the northern Sardinia, were part of the same regional-scale dextral shear zone system known as the East Variscan Shear Zone. Its activity is now well constrained in four of its branches and is related to Carboniferous transpression and not to post Variscan deformation.

The same approach used in the last years to investigate the branches of the EVSZ should always be applied when dealing with regional-scale structures with complex and polyphasic evolution. Different independent analytical methods should always be systematically applied in order to obtain data capable of addressing questions on regional/ continent-scale tectonics.

\section{ACKNOWLEDGEMENTS}

I wish to greatly acknowledge my supervisors Rodolfo Carosi and Chiara Montomoli for always giving me great support and for the many interesting opportunities that they give me in those years. Salvatore Iaccarino is acknowledged for the help and support he gave me during the whole Phd project. Alessandro Petroccia is thanked for his help during the activity in the Maures Massif. Richard D. Law is acknowledged for his help with the quartz fabric analysis and John

M. Cottle is acknowledged for his help with petrochronology. Antonio Langone and Stefano Zanchetta are thanked for their review which improved the quality of the paper.

\section{REFERENCES}

Advokaat E.L., van Hinsbergen D.J.J., Maffione M., Langereis C.G. Vissers R.L.M., Cherchi A., Schroeder R., Madani H. \& Columbu S. (2014) - Eocene rotation of Sardinia, and the paleogeography of the western Mediterranean region. Earth Planet. Sci. Lett., 401, 183-195. https://doi.org/10.1016/j.epsl.2014.06.012

Arthaud F. \& Matte P. (1977) - Late Paleozoic strikeslip faulting in southern Europe and northern Africa; result of a right-latera shear zone between the Appalachians and the Urals. Geol. Soc. Am. Bull., 88, 1305-1320. 
Ballèvre M., Manzotti P. \& Dal Piaz G.V. (2018) - Pre-Alpine (Variscan) Inheritance: A Key for the Location of the Future Valaisan Basin (Western Alps). Tectonics, 37, 786-817. https://doi. org/10.1002/2017TC004633.

Bellot J.-P. (2005) - The Palaeozoic evolution of the Maures massif (France) and its potential correlation with other areas of the Variscan belt: a review. Journal of the Virtual Explorer, 19. https:// doi.org/10.3809/jvirtex.2005.00116.

Braden Z., Godin L. \& Cottle J.M. (2017) - Segmentation and rejuvenation of the Greater Himalayan sequence in western Nepal revealed by in situ $\mathrm{U}-\mathrm{Th} / \mathrm{Pb}$ monazite petrochronology. Lithos, 284-285, 751-765. https://doi.org/10.1016/j.lithos.2017.04.023.

Burg J.-P. \& Matte P. (1978) - A cross section through the French Massif Central and the scope of its Variscan Geodynamic Evolution. Zeitschrift Der Deutschen Geologischen Gesellschaft, 129, 429-460.

Carosi R., Petroccia A., Iaccarino S., Simonetti M., Langone A. \& Montomoli C. (2020) - Kinematics and timing constraints in a transpressive tectonic regime: the example of the Posada-Asinara shear zone (NE Sardinia, Italy). Geosciences, 10(8), 288. https:// doi.org/10.3390/geosciences10080288.

Carosi R., D’Addario E., Mammoliti E., Montomoli C. \& Simonetti M. (2016) - Geology of the northwestern portion of the FerriereMollieres Shear Zone, Argentera Massif, Italy. Journal of Maps, 12, 466-475. https://doi.org/10.1080/17445647.2016.1243491.

Carosi R., Montomoli C., Tiepolo M. \& Frassi C. (2012) Geochronological constraints on post-collisional shear zones in the Variscides of Sardinia (Italy): Post-collisional shear zones in the Variscides of Sardinia. Terra Nova, 24, 42-51. https://doi. org/10.1111/j.1365-3121.2011.01035.x.

Carosi R. \& Palmeri R. (2002) - Orogen-parallel tectonic transport in the Variscan belt of northeastern Sardinia (Italy): implications for the exhumation of medium-pressure metamorphic rocks. Geol. Mag., 139. https://doi.org/10.1017/S0016756802006763.

Compagnoni R., Ferrando S., Lombardo B., Radulesco N. \& Rubatto D. (2010) - Paleo-European crust of the Italian Western Alps: Geological history of the Argentera Massif and comparison with Mont Blanc-Aiguilles Rouges and Maures-Tanneron Massifs. Journal of the Virtual Explorer, 36. https://doi.org/10.3809/ jvirtex.2010.00228.

Corsini M. \& Rolland Y. (2009) - Late evolution of the southern European Variscan belt: Exhumation of the lower crust in a context of oblique convergence. C.R. Geosc., 341, 214.223. https:// doi.org/10.1016/j.crte.2008.12.002.

Cruciani G., Montomoli C., Carosi R., Franceschelli M. and Puxeddu M. (2015) - Continental collision from two perspectives: a review of Variscan metamorphism and deformation in northern Sardinia. Periodico di Mineralogia, 84, 657-699. https://doi. org/10.2451/2015PM0455.

Dawers N.H. \& Anders M.H. (1995) - Displacement-length scaling and fault linkage. J Struct Geol, 17, 607-614. https://doi.org/10.1016/01918141(94)00091-D.

Di Vincenzo G., Carosi R. \& Palmeri R. (2004) - The Relationship between Tectono-metamorphic Evolution and Argon Isotope Records in White Mica: Constraints from in situ 40Ar-39Ar Laser Analysis of the Variscan Basement of Sardinia. J. Petrol., 45, 1013-1043. https://doi.org/10.1093/petrology/egh002.

Dias R. \& Ribeiro A. (1995) - The Ibero-Armorican Arc: A collision effect against an irregular continent? Tectonophysics, 246, 113128.

Dias R., Ribeiro A., Romão J., Coke C. \& Moreira N. (2016) - A review of the arcuate structures in the Iberian Variscides; constraints and genetic models. Tectonophysics, 681, 170-194. https://doi org/10.1016/j.tecto.2016.04.011.

Dobmeier C. \& Raumer J.F.V. (1995) - Significance of latest-Variscan and Alpine deformation for the evolution of Montagne de Pormenaz (Southwestern Aiguilles Rouges massif, Western Alps). https://doi.org/10.5169/SEALS-167675.

Engi M., Lanari P. \& Kohn M. J. (2017) - Significant Ages-An introduction to petrochronology: methods and applications. In M. Engi, P. Lanari, \& M. J. Kohn (Eds.), Petrocronology: Methods and applications. Reviews in Mineralogy and Geochemistry, 83, 1-12. Chantilly, Virginia, USA: Mineralogical Society of America and the Geochemical Society. https://doi.org/10.1515/9783110561890$\underline{002}$.
Faleiros F.M., Moraes R., Pavan M. \& Campanha G.A.C. (2016) - A new empirical calibration of the quartz c-axis fabric openingangle deformation thermometer. Tectonophysics, 671, 173-182. https://doi.org/10.1016/j.tecto.2016.01.014.

Faure-Muret A. (1955) - Etudes géologiques sur le massif de l'ArgenteraMercantour et ses enveloppes sédimentaires. Mémoires pour servir à l'explication de la Carte géologique détaillée de la France, Paris, Imprimerie Nationale, France. 336 pp., with 'Esquisse Géologique du Massif de l'Argentera-Mercantour et de sa Bordure Sédimentaire (Versant français)' at the 1/100.000 scale.

Faure M., Lardeaux J.-M. \& Ledru P. (2009) - A review of the prePermian geology of the Variscan French Massif Central. C.R. Geosci., 341, 202-213. https://doi.org/10.1016/j.crte.2008.12.001.

Fernández-Lozano J., Pastor-Galán D., Gutiérrez-Alonso G. \& Franco P. (2016) - New kinematic constraints on the Cantabrian orocline: A paleomagnetic study from the Peñalba and Truchas synclines, NW Spain. Tectonophysics, 681, 195-208. https://doi.org/10.1016/j. tecto.2016.02.019.

Ferrara G. \& Malaroda R. (1969) - Radiometric age of granitic rocks from the Argentera Massif (maritime Alps). Boll. Soc. geol. Ital., $88,311-320$.

Fluck P., Piqué A., Schneider J.L. \& Whitechurch H. (1991) - Le socle vosgien. Sciences Géologiques, 44, 207-235.

Fossen H. (2016) - Structural geology, Second edition. ed. Cambridge University Press, Cambridge, United Kingdom.

Fossen H., Basil T. \& Christian T. (1994) - Strain modeling of transpressional and transtensional deformation. Norsk Geologisk Tidsskrift, 74, 134-145.

Fossen H. \& Cavalcante G.C.G. (2017) - Shear zones - A review. EarthSci. Rev., 171, 434-455. https://doi.org/10.1016/j.earscirev.2017.05.002

Fossen H. \& Tikoff B. (1993) - The deformation matrix for simultaneous simple shearing, pure shearing and volume change, and its application to transpression-transtension tectonics. J. Struct. Geol., 15, 413-422. https://doi.org/10.1016/0191-8141(93)90137-Y.

Franke W., Cocks L.R.M. \& Torsvik T.H. (2017) - The Palaeozoic Variscan oceans revisited. Gondwana Res., 48, 257-284. https://doi. org/10.1016/j.gr.2017.03.005.

Fry N. (1979) - Random point distribution and strain measurement in rocks. Tectonophysics, 89-105.

García-Navarro E. \& Fernández C. (2004) - Final stages of the Variscan orogeny at the southern Iberian massif: Lateral extrusion and rotation of continental blocks. Tectonics, 23, TC6001. https://doi. org/10.1029/2004TC001646.

Genier F., Bussy F., Epard J.-L. \& Baumgartner L. (2008) - Waterassisted migmatization of metagraywackes in a Variscan shear zone, Aiguilles-Rouges massif, western Alps. Lithos, 102, 575-597. https://doi.org/10.1016/j.lithos.2007.07.024.

Gerbault M., Schneider J., Reverso-Peila A. \& Corsini M. (2016) Crustal exhumation during ongoing compression in the Variscan Maures-Tanneron Massif, France-Geological and thermomechanical aspects. Tectonophysics, 746, 439-458. https://doi. org/10.1016/j.tecto.2016.12.019.

Gillam B.G., Little T.A., Smith E. \& Toy V.G. (2013) - Extensional shear band development on the outer margin of the Alpine mylonite zone, Tatare Stream, Southern Alps, New Zealand. J. Struct. Geol., 54, 1-20. https://doi.org/10.1016/j.jsg.2013.06.010.

Graziani R., Montomoli C., Iaccarino S., Menegon L., Nania L. \& Carosi R. (2020) - Structural setting of a transpressive shear zone: Insights from geological mapping, quartz petrofabric and kinematic vorticity analysis in NE Sardinia (Italy). Geol. Mag. 1-19. https://doi.org/10.1017//S0016756820000138.

Iaccarino S., Montomoli C., Carosi R., Montemagni C., Massonne H.J., Langone A., Jain A.K. \& Visonà D. (2017) - Pressure-temperaturedeformationtime constraints on the South Tibetan Detachment System in the Garhwal Himalaya (NW India). Tectonics, 36, 22812304. https://doi.org/10.1002/2017TC004566.

Jouffray F., Spalla M.I., Lardeaux J.M., Filippi M., Rebay G., Corsini M., Zanoni D., Zucali M. \& Gosso G. (2020) - Variscan eclogites from the Argentera-Mercantour Massif (External Crystalline Massifs, SW Alps): a dismembered cryptic suture zone. Int. J. Earth Sci., 109, 1273-1294. https://doi.org/10.1007/s00531-020-01848$\underline{2}$.

Kylander-Clark, A., Hacker, B. \& Cottle., J.M. (2013) - Laser Ablation Split-Stream ICP Petrochronology: Chem. Geol., 345, 99-112. https://doi.org/10.1016/j.chemgeo.2013.02.019. 
Kroner U. \& Romer R.L. (2013) - Two plates - Many subduction zones: The Variscan orogeny reconsidered. Gondwana Res., 24 298-329. https://doi.org/10.1016/j.gr.2013.03.001.

Kruhl J.H. (1998) - Reply: prism- and basal-plane parallel subgrain boundaries in quartz: a microstructural geothermobarometer. J. Metamorph. Geol., 16, 142-146.

Kurz G.A. \& Northrup C.J. (2008) - Structural analysis of mylonitic rocks in the Cougar Creek Complex, Oregon-Idaho using the porphyroclast hyperbolic distribution method, and potential use of SC'-type extensional shear bands as quantitative vorticity indicators. J. Struct. Geol., 30, 1005-1012. https://doi.org/10.1016/j. jsg.2008.04.003

Law R.D. (2014) - Deformation thermometry based on quartz c-axis fabrics and recrystallization microstructures: A review. J. Struct. Geol., 66, 129-161. https://doi.org/10.1016/i.jsg.2014.05.023.

Malaroda R., Carraro F., Dal Piaz G.V., Franceschetti B., Sturani C. \& Zanella E. (1970) - Carta geologica del Massiccio dell'Argentera alla scala 1: 50.000 e note illustrative. Memorie Della Società Geologica Italiana, 9, 557-663.

Matte P. (2001) - The Variscan collage and orogeny (480-290 Ma) and the tectonic definition of the Armorica microplate: a review. Terra Nova, 13, 122-128.

Matte P. (1986) - La Chaîne varisque parmi les chaînes paléozoïques péri-atlantiques, modèle d'évolution et position des grands blocs continentaux au Permo-Carbonifère. Bull. Soc. Geol. Fr., 8, 4-24.

Montomoli C., Iaccarino S., Carosi R., Langone A. \& Visonà D. (2013) - Tectonometamorphic discontinuities within the Greater Himalayan Sequence in Western Nepal (Central Himalaya): Insights on the exhumation of crystalline rocks. Tectonophysics, 608, 1349-1370. https://doi.org/10.1016/j.tecto.2013.06.006.

Muttoni G. \& Kent D.V. (2019) - Adria as promontory of Africa and its conceptual role in the Tethys Twist and Pangea B to Pangea A Transformation in the Permian. Riv. It. Paleontol. Strat., 125(1), 249-269.

Muttoni G., Gaetani M., Kent D.V., Sciunnach D., Angiolini L., Berra F., Garzanti E., Mattei M. \& Zanchi A. (2009) - Opening of the Neo-Tethys Ocean and the Pangea B to Pangea A transformation during the Permian. https://doi.org/10.7916/D8SF2TXF.

Muttoni G., Kent D.V., Garzanti E., Brack P., Abrahamsen N. \& Gaetani M. (2003) - Early Permian Pangea 'B' to Late Permian Pangea 'A'率. Earth Planet. Sci. Lett., 215, 379-394. https://doi org/10.1016/S0012-821X(03)00452-7.

Oliot E., Melleton J., Schneider J., Corsini M., Gardien V. \& Rolland Y. (2015) - Variscan crustal thickening in the Maures-Tanneron massif (South Variscan belt, France): new in situ monazite U-Th$\mathrm{Pb}$ chemical dating of high-grade rocks. Bull. Soc. géol. Fr., 186 , 145-169. https://doi.org/10.2113/gssgfbull.186.2-3.145.

Padovano M., Dörr W., Elter F.M. \& Gerdes A. (2014) - The East Variscan Shear Zone: Geochronological constraints from the Capo Ferro area (NE Sardinia, Italy). Lithos, 196-197, 27-41. https://doi.org/10.1016/j.lithos.2014.01.015.

Padovano M., Elter F.M., Pandeli E. \& Franceschelli M. (2012) - The East Variscan Shear Zone: new insights into its role in the Late Carboniferous collision in southern Europe. Int. Geol. Rev., 54, 957-970. https://doi.org/10.1080/00206814.2011.626120.

Passchier C.W. (1987) - Stable position of rigid objects in non-coaxial flow: a study in vorticity analysis. J. Struct. Geol., 9, 679-690.

Pereira M.F., Apraiz A., Silva J.B. \& Chichorro M. (2008) Tectonothermal analysis of high-temperature mylonitization in the Coimbra-Córdoba shear zone (SW Iberian Massif, Ouguela tectonic unit, Portugal): Evidence of intra-continental transcurrent transport during the amalgamation of Pangea. Tectonophysics, 461, 378-394. https://doi.org/10.1016/j.tecto.2007.11.042.

Piazolo S. \& Passchier C.W. (2002) - Experimental modeling of viscous inclusions in a circular high-strain shear rig: Implications for the interpretation of shape fabrics and deformed enclaves: Experimental Modeling of Viscous Inclusions. J. Geophys. Res. Solid Earth, 107, ETG 11-1-ETG 11-15. https://doi. org/10.1029/2000JB000030.

Pohl F., Froitzheim N., Obermüller G., Tomaschek F., Schröder O., Nagel T.J., Sciunnach D. \& Heuser A. (2018) - Kinematics and Age of Syn-Intrusive Detachment Faulting in the Southern Alps: Evidence for Early Permian Crustal Extension and Implications for the Pangea A Versus B Controversy. Tectonics, 37, 3668-3689. https://doi.org/10.1029/2018TC004974.
Pyle J. M., \& Spear F. S. (1999) - Yttrium zoning in garnet: Coupling of major and accessory phases during metamorphic reactions. Geological Materials Research, 1, 1-49.

Pyle J. M., Spear F. S., Rudnick R. L., \& McDonough W. F. (2001) Monazite-xenotime-garnet equilibrium in metapelites and a new monazite-garnet thermometer. Journal of Petrology, 42, 2083 2107.

Rollet N., Déverchère J., Beslier M.-O., Guennoc P., Réhault J.-P., Sosson M. \& Truffert C. (2002) - Back arc extension, tectonic inheritance, and volcanism in the Ligurian Sea, Western Mediterranean: Ligurian Sea back arc structure and evolution. Tectonics, 21, 6-1-6-23. https://doi.org/10.1029/2001TC900027.

Rosenbaum G., Lister G.S. \& Duboz C. (2002) Reconstruction of the tectonic evolution of the western Mediterranean since the Oligocene. Journal of the Virtual Explorer, 08. https://doi. org/10.3809/jvirtex.2002.00053.

Schneider J., Corsini M., Reverso-Peila A. \& Lardeaux J.-M. (2014) Thermal and mechanical evolution of an orogenic wedge during Variscan collision: an example in the Maures-Tanneron Massif (SE France). Geol. Soc. Spec. Publ., 405, 313-331. https://doi. org/10.1144/SP405.4.

Schulmann K., Konopásek J., Janoušek V., Lexa O., Lardeaux J.M., Edel J.-B., Štípská P. \& Ulrich S. (2009) - An Andean type Palaeozoic convergence in the Bohemian Massif. C. R. Geosci., 341, 266-286. https://doi.org/10.1016/j.crte.2008.12.006.

Scotese C.R. \& McKerrow W.S. (1990) - Revised World maps and introduction. Geol. Soc. Lond. Mem., 12, 1-21. https://doi. org/10.1144/GSL.MEM.1990.012.01.01.

Simonetti M., Carosi R. \& Montomoli C. (2021a) - Strain softentening in a continental shear zone: a field guide to the excursion in the Ferriere-Mollières Shear Zone (Argentera Massif, Western Alps, Italy). Structural Geology \& Field Guidebook - Volume 1(Springer), edited by Mukherjee S., Springer Geology, 19-48. https://doi.org/10.1007/978-3-030-60143-0_2 2 .

Simonetti M., Carosi R., Montomoli C. \& Iaccarino S. (2021b) - The role of regional-scale shear zones in paleogeographic reconstructions: the case study of the Variscan belt in the Mediterranean area, EGU General Assembly 2021, online, 19-30 Apr 2021, EGU218673, https://doi.org/10.5194/egusphere-egu21-8673.

Simonetti M., Carosi R., Montomoli C., Law R. D. \& Cottle J. M. (2021c) - Unravelling the development of regional-scale shear zones by a multidisciplinary approach: The case study of the Ferriere-Mollìeres Shear Zone (Argentera Massif, Western Alps). J. Struct. Geol., 149, 104399. https://doi.org/10.1016/j.jsg.2021.104399.

Simonetti M., Carosi R., Montomoli C., Cottle J.M. \& Law R.D. (2020a). Transpressive Deformation in the Southern European Variscan Belt: New Insights from the Aiguilles Rouges Massif (Western Alps). Tectonics, 39. https://doi.org/10.1029/2020TC006153.

Simonetti M., Carosi R., Montomoli C., Corsini M., Petroccia A., Cottle J.M. \& Iaccarino S. (2020b). Timing and kinematics of flow in a transpressive dextral shear zone, Maures Massif (Southern France). Int. J. Earth Sci., 109, 2261-.2285. https://doi.org/10.1007/ s00531-020-01898-6.

Simonetti M., Carosi R., Montomoli C., Langone A., D'Addario E. \& Mammoliti E. (2018) - Kinematic and geochronological constraints on shear deformation in the Ferriere-Mollières shear zone (Argentera-Mercantour Massif, Western Alps): implications for the evolution of the Southern European Variscan Belt. Int. J. Earth Sci., 107, 6, 2163-2189. https://doi.org/10.1007/s00531-0181593-y.

Simonetti M., Carosi R. \& Montomoli C. (2017). Variscan shear deformation in the Argentera Massif: a field guide to the excursion in the Pontebernardo Valley (CN, Italy). Atti Soc. Tosc. Sci. Nat., Mem., Serie A, 124, 151-169. https://doi.org/10.2424/ ASTSN.M.2017.25.

Skrzypek E., Štípská P. \& Cocherie A. (2012) - The origin of zircon and the significance of U-Pb ages in high-grade metamorphic rocks: a case study from the Variscan orogenic root (Vosges Mountains, NE France). Contrib. to Mineral. Petrol., 164, 935-957. https://doi. org/10.1007/s00410-012-0781-1.

Soliva R. \& Benedicto A. (2004) - A linkage criterion for segmented normal faults. J. Struct. Geol., 26, 2251-2267. https://doi. org/10.1016/j.jsg.2004.06.008.

Soliva R., Benedicto A. \& Maerten L. (2006) - Spacing and linkage of confined normal faults: Importance of mechanical thickness. J. Geophys. Res., 111, B01402. https://doi.org/10.1029/2004JB003507. 
Stampfli G.M., Borel G.D., Marchant R. \& Mosar J. (2002) - Western Alps geological constraints on western Tethyan reconstructions. Journal of the Virtual Explorer, 8, 77.

Stipp M., Stunitz H., Heilbronner R. \& Schmid S.M. (2002) - The eastern Tonale fault zone: A "natural laboratory" for crystal plastic deformation of quartz over a temperature range from 250 to $700^{\circ}$ C. J. Struct. Geol., 24, 1864-1884.

Tapponnier P. \& Molnar P. (1977) - Active faulting and tectonics in China. J. Geophys. Res., 82, 2905-2930. https://doi.org/10.1029/ JB082i020p02905.

Tapponnier P., Peltzer G., Le Dain A.Y., Armijo R. \& Cobbold P. (1982) - Propagating extrusion tectonics in Asia: New insights from simple experiments with plasticine. Geology, 10, 611-616. https:// doi.org/10.1130/0091-7613(1982)10<611:PETIAN>2.0.CO;2.

Tollmann A. (1982) - Großraumiger variszischer Deckenbau im Moldanubikum und neue Gedanken zum Variszikum Europas. Geotektonische Forschungen 64, 1-91.

Trudgill B. \& Cartwright J. (1994) - Relay-ramp forms and normalfault linkages, Canyonlands National Park, Utah. GSA Bulletin, 106, 1143-1157. https://doi.org/10.1130/0016-7606(1994)106<1143:RRF $\mathrm{ANF}>2.3 . \mathrm{CO} ; 2$.

Turco E., Macchiavelli C., Mazzoli S., Schettino A. \& Pierantoni P.P. (2012) - Kinematic evolution of Alpine Corsica in the framework of Mediterranean mountain belts. Tectonophysics, 579, 193-206. https://doi.org/10.1016/j.tecto.2012.05.010.
Von Raumer J. \& Bussy F. (2004) - Mont Blanc and Aiguilles Rouges geology of their polimetamorphic basement, Mémoires de Géologie. Lausanne.

Wallis S. (1995) - Vorticity analysis and recognition of ductile extension in the Sanbagawa belt, SW Japan. J. Struct. Geol., 17 1077-1093. https://doi.org/10.1016/0191-8141(95)00005-X.

Wallis S.R., Platt J.P. \& Knott S.D. (1993) - Recognition of synconvergence extension in accretionary wedges with examples from Calabrian arc and the Eastern Alps. Am. J. Sci., 293, 463495.

Walsh J.J., Bailey W.R., Childs C., Nicol A. \& Bonson C.G. (2003) Formation of segmented normal faults: a 3-D perspective. J. Struct. Geol., 25, 1251-1262. https://doi.org/10.1016/S0191-8141(02)00161-X.

Walsh J.J., Nicol A. \& Childs C. (2002) - An alternative model for the growth of faults. J. Struct. Geol., 24, 1669-1675. https://doi. org/10.1016/S0191-8141(01)00165-1.

Williams M.L., Jercinovic M.J., \& Hetherington C.J. (2007) Microprobe monazite geochronology: Understanding geologic processes by integrating composition and chronology. Annual Review of Earth and Planetary Sciences, 35, 137-175. https://doi. org/10.1146/annurev.earth.35.031306.140228.

Xypolias P. (2010) - Vorticity analysis in shear zones: A review of methods and applications. J. Struct. Geol., 32, 2072-2092. https:// doi.org/10.1016/j.jsg.2010.08.009 